\title{
25 Research Soure \\ Prevalence of long-acting reversible contraceptive uses and predictors among Ethiopian women over the past five years. A systematic review and meta-analysis
}

Dereje Lemma Dube ( $\square$ lemma.dereje@yahoo.com )

Ambo university

Shimekit Yilma

Ambo University

Legese Chelkeba

Addis Ababa University

Systematic Review

Keywords: Prevalence, associated factors, meta-analysis, Ethiopia

Posted Date: January 18th, 2022

DOI: https://doi.org/10.21203/rs.3.rs-1267420/v1

License: (9) (1) This work is licensed under a Creative Commons Attribution 4.0 International License. Read Full License 


\section{Abstract \\ Objective}

LARCs are a type of long-acting reversible contraception that is both safe and cost-effective for women. The aim of this review was to determine the pooled prevalence of LARC users and associated factors among Ethiopian women over the last five years.

\section{Study design}

: We searched Pub Med, Scopus, Science Direct, Web of Science, and Google Scholar on data published between 2017 to February 2021. The 12 index was used to measure heterogeneity between studies and subgroup analysis and leave one sensitivity analysis to determine possible causes of heterogeneity

\section{Results}

Among 440 studies identified, 75 were selected for a full review, and 27 met the inclusion criteria. Long-acting reversible contraceptives (LACs) users were detected in 3,588 of the 12,741 women studied, yielding a $29 \%$ overall prevalence (95\% Cl: $13-20 \%)$. Previous use of LARC was associated with being four times $(P=0.001,95 \%$ $\mathrm{Cl}$ 2.55-4.57) more likely to use LARCs, women with a positive attitude towards birth control $(\mathrm{P}=0.001,95 \% \mathrm{Cl}$ 1.5-2.3), and good knowledge ( $p=0.001,95 \% \mathrm{Cl} 1.16-1.98)$ were two times more likely to use LARC.

\section{Conclusion}

prevalence of LARC was low among Ethiopian women, and knowledge, attitude, and previous use of LARC affects its prevalence

\section{Introduction}

Higher maternal mortality, total fertility, and population growth rates, as well as an unmet need for family planning, were all indicators of significant population growth and reproductive health issues in Sub-Saharan Africa, including Ethiopia. There was a larger proportion of unmet family planning needs in several Sub-Saharan African nations, particularly for long-acting methods $(1,2)$. Simply by lowering the incidence of unwanted births, increasing contraceptive usage in poorer nations has reduced maternal mortality by $40 \%$ in the last 20 years (3). Increased contraceptive usage has decreased the maternal mortality ratio-the risk of maternal death per 100 000 live births-by around $26 \%$ in just over a decade by avoiding high-risk pregnancies, notably among women of high parities, and those that would have resulted in unsafe abortion.

Contraception has become an essential component in the lives of women of reproductive age since it avoids the depletion of maternal nutritional reserves and lowers the risk of anaemia caused by many pregnancies and deliveries(4).LARCs are a type of long-acting reversible contraception that is both safe and cost-effective for women who want to postpone or restrict their pregnancies but do not need daily user compliance. The intrauterine device (IUD) and hormonal implants are both convenient for users and successful in preventing 
pregnancy. $(5,6)$. Long-acting reversible family planning methods offer women continuous protection for 3 to 12 years and are by far the most successful ( $99 \%$ or higher) and highly safe. They are also cost-effective for programs over time, may save governments a lot of money, and directly contribute to national and international health goals (7)and are the most effective (between 3 and 60 times more effective than short-acting methods during a year of average usage) and need little activity from the client (7). Despite these benefits, they are typically difficult to get for customers and are not as extensively utilized as other methods, particularly in Africa(8).Ethiopia's Federal Ministry of Health established a health-sector transformation strategy, promising to use LARC procedures 40 percent of the time by 2020(9).

To the best of our knowledge, the prevalence of LARC use among Ethiopian women over the last five years not reviewed and the result of this review might provide essential information for the governmental sector, policy maker, public health educator and clinicians. Therefore, this review aimed at presenting a comprehensive data on overall prevalence and predictors of LARC users among women in Ethiopia for the past five years.

\section{Methods}

\section{Search strategy and Reporting}

We conducted a search for all peer-reviewed published articles on prevalence of LARCs use and predictors among Ethiopian women using PubMed, Science Direct, Scopus, Web of Science, and Google Scholar databases from December 2017 to May 2021. A combination of Medical Subject Headings or key search terms included: LARC AND Ethiopia AND prevalence, modern contraceptives AND Ethiopia, LARC AND Ethiopia AND associated factors, LARC AND risk factors AND Ethiopia, LARC AND associated factors AND Ethiopia, LARC AND Ethiopia AND risk factors OR associated factors to find relevant original papers in Pub Med, we employed medical topic headings (Mesh words). Three authors (DL, SHY, and $\mathrm{LCH}$ ) conducted the review and the most relevant papers were chosen based on established inclusion and exclusion criteria. The final author double-checked the consistency of the search method, research selection, and inclusion and exclusion criteria. These systematic reviews and meta-analyses followed the PRISMA 20 (Preferred Reporting Items for Systematic Reviews and Meta-analysis) standard(10).

\section{INCLUSION AND EXCLUSION CRITERIA}

Original Ethiopian researches were included in this comprehensive review and meta-analysis, but comments, editorials, case reports, and reviews were not. Articles were considered if they calculated the proportion/prevalence and/or risk factors/ associated factors or determinants of LARC among women in Ethiopia over the past five years, omitting those published papers didn't determine prevalence or proportion of LARC or if the language of publication wasn't English or if the publication was before 2017.

\section{DATA EXTRACTION}

Data abstraction was conducted by two writers (DL, SHY) utilizing an excel spread sheet form. Using inclusion criteria, these authors separately assessed titles, abstracts, full-text publications, and abstracted data. Discrepancies between the two authors who largely abstracted the data were arbitrated by the third author $(\mathrm{LCH})$. The following parameters were extracted from each study: the name of first author, year of publication, regions, study settings and design, age, the type of study, risk factors or associated factors, the number of 
women who participated in the study, the number of women used LARC, the prevalence/proportion of women used LARC, number and percentage of women used Implanon, IUCD, and Jadelle.

\section{STATISTICAL ANALYSIS}

We used forest plots to estimate the pooled impact size and effect of each review, as well as their confidence intervals, to provide a visual overview of the data $(\mathrm{Cl})$. A random-effect model was used in this meta-analysis due to the anticipated heterogeneity. To indicate statistical heterogeneity among studies, the $p$ value, Cochrane test (Q-test), and $\mathrm{I}^{2}$ were employed, with p-values of 0.05 and $\mathrm{I} 2$ values of $0,25,50$, and 75 percent indicating no, low, moderate, and high heterogeneity, respectively. We used Egger's regression test as well as visual assessment for plot symmetry to conduct a quantitative analysis of the possibility of publication bias. We also performed subgroup analyses based on types of LARC and regional states of the country. We also did sensitivity test by leave-one sensitivity analysis utilizing sample size, study setting, and study area as covariates, as well as determining variables linked to LARC usage. All mentioned p-values were two-sided and statistically significant when $\mathrm{p}<0.05$.

\section{Results}

\section{Literature identification and Descriptions of studies}

Two hundred duplicates were discovered after examining the titles and abstracts of the 440 papers found. We also excluded 80 studies because they failed to mention LARC in Ethiopia. A total of 160 studies were evaluated based on their themes and abstracts; with 60 being removed since they were presented in mixed method (includes all modern contraception). Finally, the full text of the remaining 75 publications was downloaded and extensively checked to confirm that they complied with all of the criteria for inclusion. We also eliminated 35 articles because they were published before 2017, ten publications because they didn't reflect the prevalence of LARC, and three publications because they reported the rationale for implanon early termination. Finally, twentyseven studies met the review's inclusion criteria (11-37) (Figure1).

Fourteen studies were conducted at health facilities $(11,12,14,15,20,22,23,26,29-31,34,35,37)$, while thirteen studies were conducted at the community level(13, 16-19, 21, 24, 25, 27, 28, 32, 33, 36)and all of the studies were cross sectional in design (11-37). The studies included our review were published between 2017 and 2021(1137).

The study subjects in twenty-four investigations were women of reproductive age $((11,13-16,18-33,35-37)$, three were about postpartum women $(12,28,34)$, one study was about HIV/AIDS-positive women of reproductive age(20), and one study was about female health professionals of reproductive age (15). The average age of study participants was ranged from $25(33)$ to $36(37)$ years old, with a range of $15-49$ years $(17,19)$. Six studies were done in the Oromia region(12, 19, 23, 24, 29, 31), nine studies in the Amhara region(13-15, 17, 20, 21, 26, 35, 37)and nine studies in SNNP region $(16,18,19,22,27,28,33,34,36)$, and one study each in the Afar region (11), Harari region(30) ,and Addis Ababa city administration(32). Sample size of included studies ranges from 262(27) to 731(36) and prevalence of LARC users among Ethiopian women over the last five years ranges from $12.6 \%(21)$ to $53.2 \%(12)$. Twenty-four studies $(13-15,17,19-37)$ report IUCD and implanon prevalence, with just 
one study reporting Jadelle prevalence in addition to IUCD and implanon(12). Twenty-six studies were carried out in urban (11-34, 36, 37), while only one study was carried out in rural areas(35) (Table1).

Table1. Characteristics of studies included in systematic review and meta-analysis 


\begin{tabular}{|c|c|c|c|c|c|c|c|c|}
\hline Author & $\begin{array}{l}\text { Year of } \\
\text { publication }\end{array}$ & Region & $\begin{array}{l}\text { Study } \\
\text { design } \\
\text { and } \\
\text { setting } \\
\text { Facility } \\
\text { based } \\
\text { cross }\end{array}$ & $\begin{array}{l}\text { Women of } \\
\text { reproductive }\end{array}$ & $\begin{array}{l}\text { Age } \\
\text { (mean/ } \\
\text { range) }\end{array}$ & $\begin{array}{l}\text { Sample } \\
\text { size }(\mathrm{N})\end{array}$ & $\begin{array}{l}\text { Sample } \\
\text { size(n) }\end{array}$ & $\begin{array}{l}\text { Prevalence } \\
\text { of } \\
\text { LARC(\%) }\end{array}$ \\
\hline (31) & 2017 & Oromia & $\begin{array}{l}\text { sectional } \\
\text { Community } \\
\text { based } \\
\text { cross }\end{array}$ & age & $15-49$ & 422 & 97 & 22.9 \\
\hline $\begin{array}{l}\text { Mesfin } \\
(28)\end{array}$ & 2021 & SNNP & sectional & $\begin{array}{l}\text { Post partum } \\
\text { women }\end{array}$ & 28.2 & 416 & 94 & 22.6 \\
\hline Shiferaw & & & $\begin{array}{l}\text { Facility } \\
\text { based } \\
\text { cross }\end{array}$ & $\begin{array}{l}\text { Women of } \\
\text { reproductive }\end{array}$ & & & & \\
\hline (30) & 2017 & Harar & $\begin{array}{l}\text { sectional } \\
\text { Facility } \\
\text { based }\end{array}$ & age & 26.7 & 402 & 153 & 38 \\
\hline $\begin{array}{l}\text { Wariyo } \\
(12)\end{array}$ & 2019 & Oromia & $\begin{array}{l}\text { cross } \\
\text { sectional } \\
\text { Facility } \\
\text { based }\end{array}$ & $\begin{array}{r}\text { Post partum } \\
\text { women }\end{array}$ & 27 & 393 & 209 & 53.2 \\
\hline $\begin{array}{l}\text { Woldu } \\
\text { (34) }\end{array}$ & 2020 & SNNP & $\begin{array}{l}\text { cross } \\
\text { sectional } \\
\text { Community } \\
\text { based } \\
\text { cross } \\
\text { sectional }\end{array}$ & $\begin{array}{l}\text { Post partum } \\
\quad \text { women } \\
\text { Women of } \\
\text { reproductive } \\
\text { age }\end{array}$ & 27 & 381 & 139 & 36.5 \\
\hline $\operatorname{Biza}(17)$ & 2017 & Amhara & $\begin{array}{l}\text { Facility } \\
\text { based } \\
\text { cross }\end{array}$ & $\begin{array}{l}\text { Women of } \\
\text { reproductive } \\
\text { age }\end{array}$ & $15-49$ & 381 & 111 & 29.1 \\
\hline Gujo(22) & 2021 & SNNP & $\begin{array}{l}\text { sectional } \\
\text { Cross } \\
\text { sectional } \\
\text { Community } \\
\text { based } \\
\text { cross }\end{array}$ & $\begin{array}{l}\text { Women of } \\
\text { reproductive } \\
\text { age }\end{array}$ & 27.1 & 376 & 142 & 37.8 \\
\hline Halil(25) & 2020 & SNNP & $\begin{array}{l}\text { sectional } \\
\text { Facility } \\
\text { based } \\
\text { cross }\end{array}$ & $\begin{array}{l}\text { Women of } \\
\text { reproductive } \\
\text { age }\end{array}$ & 28.8 & 528 & 97 & 18.3 \\
\hline Mohammad(29) & 2017 & Oromia & sectional & & 25.91 & 644 & 180 & 27.9 \\
\hline $\begin{array}{l}\text { Fekadu } \\
\text { (19) }\end{array}$ & 2017 & Oromia & $\begin{array}{l}\text { Community } \\
\text { based }\end{array}$ & $\begin{array}{l}\text { Women of } \\
\text { reproductive }\end{array}$ & $15-49$ & 693 & 210 & 30.3 \\
\hline
\end{tabular}


Asteray

(14)

(n)

$\operatorname{Abdu}(11)$

Asirat

Mariam

Hibstu

Zenebe

Dereje

Samson

Aklilu

Getahun

Gelagay

$\begin{array}{ll}\text { cross } & \text { age } \\ \text { sectional } & \\ \text { Facility } & \text { Women of } \\ \text { based } & \text { reproductive }\end{array}$

cross age

2019 Amhara

sectional

Facility

based

cross

2019 Afar

sectional

Community Women of

based

reproductive

cross age

2017 SNNP sectional

Facility Women of

based reproductive

cross age

2018 Amhara sectional

Facility Women of

based reproductive

cross age

2020 Oromia sectional

Facility Women of

based reproductive

cross age

2017 Amhara sectional

Community Women of

based reproductive

cross age

2019

SNNP sectional

Community Women of

based reproductive

cross age

2020 SNNP sectional

Community Women of

based reproductive

cross age

2020 SNNP sectional

Community Women of

based reproductive

cross age

2018 Amhara sectional

Facility

based

cross

2018 Amhara

age those on

Women of

reproductive

sectional

ART

$26.71 \quad 524 \quad 175$

33.4

$30.4 \quad 262 \quad 66$

25.2

$25.9 \quad 614 \quad 207$

33.7

$\begin{array}{lll}27.4 & 361 & 121\end{array}$

33.5

$25.91 \quad 644 \quad 180$

27.9

30

561

164

29.2

$346 \quad 134$

38.7

$25 \quad 660 \quad 145$

22

27.8

730

92

12.6

31.59

505

138

27.3 


\begin{tabular}{|c|c|c|c|c|c|c|c|c|}
\hline $\begin{array}{l}\text { Teshome } \\
(32)\end{array}$ & 2018 & $\begin{array}{l}\text { Addis } \\
\text { Ababa }\end{array}$ & $\begin{array}{l}\text { Community } \\
\text { based } \\
\text { cross } \\
\text { sectional }\end{array}$ & $\begin{array}{l}\text { Women of } \\
\text { reproductive } \\
\text { age }\end{array}$ & 31.2 & 469 & 81 & 17.3 \\
\hline Alemu & & & $\begin{array}{l}\text { Facility } \\
\text { based } \\
\text { cross }\end{array}$ & $\begin{array}{l}\text { Women of } \\
\text { reproductive } \\
\text { age }\end{array}$ & & & & \\
\hline (35) & 2021 & Amhara & $\begin{array}{l}\text { sectional } \\
\text { Community } \\
\text { based } \\
\text { cross }\end{array}$ & $\begin{array}{l}\text { Women of } \\
\text { reproductive } \\
\text { age }\end{array}$ & 30.1 & 356 & 112 & 32.3 \\
\hline Yemaneh(36) & 2017 & SNNP & $\begin{array}{l}\text { sectional } \\
\text { Community } \\
\text { based } \\
\text { cross }\end{array}$ & $\begin{array}{l}\text { Women of } \\
\text { reproductive } \\
\text { age }\end{array}$ & 26.6 & 731 & 145 & 19.8 \\
\hline Asigedew(13) & 2017 & Amhara & $\begin{array}{l}\text { sectional } \\
\text { Facility } \\
\text { based } \\
\text { cross }\end{array}$ & $\begin{array}{l}\text { Women of } \\
\text { reproductive } \\
\text { age,female } \\
\text { health }\end{array}$ & 31.69 & 499 & 174 & 34.9 \\
\hline Liknaw (15) & 2019 & Amhara & $\begin{array}{l}\text { sectional } \\
\text { Community } \\
\text { based } \\
\text { cross }\end{array}$ & $\begin{array}{l}\text { professional } \\
\text { Women of } \\
\text { reproductive } \\
\text { age }\end{array}$ & 27.4 & 392 & 89 & 22.7 \\
\hline$(24)$ & 2017 & Oromia & sectional & & 30.5 & 419 & 139 & 33.2 \\
\hline
\end{tabular}

\section{Pooled prevalence estimate and heterogeneity}

The prevalence of LARC among women in Ethiopia for the last five years was reported in twenty -seven (27) studies including 12,741 women. As shown in Figure 2, among the 3,588 women used LARC, the pooled prevalence was estimated to be $29 \%$ (95\% Cl 26-32\%). The prevalence estimate differed significantly between studies $\left(X^{2}=505.29, P=0.001, I^{2}=94.85 \%\right.$

\section{Subgroup analysis based on the type of LARC}

\section{Pooled estimates of prevalence of Implanon among Ethiopian women for the last five years}

The prevalence of Implanon among women in Ethiopia for the last five years was reported in twenty-six (26) studies including 11,871 women. As shown in Figure 3, 3,588 women used LARC and the pooled prevalence of Implanon was estimated to be $23 \%$ (95\% Cl 20-26\%). The prevalence estimate differed significantly between studies $\left(X^{2}=337.79, P=0.001, I^{2}=92.6 \%\right)$.

\section{Pooled estimates of prevalence of IUCD among Ethiopian women for the last five years}


In Ethiopia, the prevalence of IUCD among women in Ethiopia for the last five years was reported in twenty -six (26) studies including 11,871 women. As shown in Figure 4, among the 3,588 women used LARC, the pooled prevalence of IUCD was estimated to be $5 \%$ (95\% Cl 4-7\%). The prevalence estimate differed significantly between studies $\left(X^{2}=506.36, P=0.001, I^{2}=95.26 \%\right)$.

\section{Subgroup analysis}

LARC users were detected in $33 \%$ (95 \% Cl 26-41\%) of Oromia, 28\% (95 \% 23-33) of SNNP region, and $27 \%$ (95 $\% \mathrm{Cl} 21-33 \%$ ) of Amhara region. We looked at sample sizes of $\leq 400$ and $>400$ since we assumed sample size may be a source of the considerable heterogeneity we identified in our study, and we found that sample size was not a major driver of heterogeneity $(p=0.001)$. Between 2017 and 2018, the estimated pooled prevalence of LARC users was 28\% (95 \% Cl 23-32\%), and between 2019 and 2021, the estimated pooled prevalence of LARC users was $30 \%$ (95 \% Cl 25-36\%), with no major source of heterogeneity. We also ran an analysis to see if the source of heterogeneity was related to the study setting, and we found that the study setting had no bearing on the cause of heterogeneity $(\mathrm{P}=0.001)$ (Table2).

Table2. Sub group analysis of the prevalence of LARC users among Ethiopian women for the last five years, 2021

\begin{tabular}{llllll}
\hline Variables & $\begin{array}{l}\text { Variable } \\
\text { categories }\end{array}$ & $\begin{array}{l}\text { Included } \\
\text { studies }\end{array}$ & $\begin{array}{l}\text { Pre } \\
\text { valence }(95 \% \\
\text { CI) }\end{array}$ & $\mathrm{I}^{2}$ & $\begin{array}{l}\text { P } \\
\text { Study setting }\end{array}$ \\
& Community & 13 & $25(21-30)$ & 94.48 & 0.001 \\
\multirow{5}{*}{ Region } & Facility & 14 & $32(28-36)$ & 92.75 & 0.001 \\
& Oromia & 6 & $33(26-41)$ & 94.84 & 0.001 \\
& Amhara & 9 & $27(21-33)$ & 95.48 & 0.001 \\
& SNNP & 9 & $28(23-33)$ & 92.89 & 0.001 \\
& Afar & 1 & $33(29-38)$ & - & - \\
Sample size & Harari & 1 & $38(33-43)$ & - & - \\
& Addis Ababa & 1 & $17(14-21)$ & - & - \\
& $>400$ & 16 & $26(23-30$ & 94.49 & 0.00 \\
Year of & $\leq 400$ & 11 & $33(27-38)$ & 93.69 & 0.00 \\
publication & & & & & \\
\hline
\end{tabular}

Year of publication $(p=0.83)$, regional state $(p=0.58)$, sample size $(p=0.85)$, and study setting $(P=0.1)$ did not exhibit any statistically significant association with prevalence of LARC usage in the previous five years in a univariate meta-regression (Table3). 
Table3. Univariate meta-regression of factors related to heterogeneity of prevalence of LARC users among Ethiopian women over the last five years

\begin{tabular}{llll}
\hline Variables & $\beta$ coefficient & $95 \%$ CI & P values \\
Regional states & 2.8418 & $-0.7-13.2$ & 0.576 \\
Study setting & -25.49 & $-56.5-5.5$ & 0.103 \\
Sample size & -4.39 & $-50.89-42.11$ & 0.847 \\
Year of publication & -1.21 & $-12-9.99$ & 0.826 \\
\hline
\end{tabular}

\section{Leave out one sensitivity analysis}

By systematically removing each study from the pooled prevalence of LARC users among Ethiopian women over the previous five years, a leave-one analysis was performed to assess the influence of each study on the pooled prevalence of LARC users among Ethiopian women over the last five years. The omitted studies had no significant impact on the projected prevalence of LARC users among Ethiopian women during the last five years, according to the findings (Table4).

Table4.leave out one analysis of the prevalence of LARC users among Ethiopian women for the last five years, 2021 


\begin{tabular}{|c|c|c|c|}
\hline Study omitted & $\begin{array}{l}\text { Estimated pool prevalence } \\
\text { with } 95 \% \text { CI }\end{array}$ & $\begin{array}{l}\text { Study } \\
\text { omitted }\end{array}$ & $\begin{array}{l}\text { Estimated pool prevalence } \\
\text { with } 95 \% \text { CI }\end{array}$ \\
\hline Wariyo (2019) & $28(25-30)$ & $\begin{array}{l}\text { Zenebe } \\
\text { (2017) }\end{array}$ & $29(26-31)$ \\
\hline Tebeje (2017) & $29(26-32)$ & $\begin{array}{l}\text { Dereje } \\
(2019)\end{array}$ & $29(26-32)$ \\
\hline $\begin{array}{l}\text { Shiferaw } \\
(2017)\end{array}$ & $29(26-31)$ & $\begin{array}{l}\text { Samson } \\
(2020)\end{array}$ & $29(26-32)$ \\
\hline Woldu (2020) & $29(26-31)$ & Aklilu (2020) & $29(26-32)$ \\
\hline Biza (2017) & $29(26-32)$ & $\begin{array}{l}\text { Getahun } \\
\text { (2018) }\end{array}$ & $29(27-32)$ \\
\hline Gujo (2021) & $29(26-31)$ & $\begin{array}{l}\text { Gelagay } \\
\text { (2018) }\end{array}$ & $29(26-32)$ \\
\hline Halil(2020) & $29(27-31)$ & $\begin{array}{l}\text { Teshome } \\
\text { (2018) }\end{array}$ & $29(27-32)$ \\
\hline $\begin{array}{l}\text { Mohammad } \\
\text { (2017) }\end{array}$ & $29(26-32)$ & $\begin{array}{l}\text { Alemu } \\
(2021)\end{array}$ & $29(27-32)$ \\
\hline Fekadu (2017) & $29(26-32)$ & $\begin{array}{l}\text { Yemaneh } \\
(2017)\end{array}$ & $29(26-32)$ \\
\hline Asteray (2019) & $29(26-32)$ & $\begin{array}{l}\text { Asigedew } \\
\text { (2017) }\end{array}$ & $29(26-31)$ \\
\hline Abdu (2019) & $29(26-31)$ & $\begin{array}{l}\text { Liknaw } \\
\text { (2019) }\end{array}$ & $29(26-32)$ \\
\hline Asirat (2017) & $29(26-32)$ & $\begin{array}{l}\text { Abebe } \\
(2017)\end{array}$ & $29(26-31)$ \\
\hline $\begin{array}{l}\text { Mariam } \\
\text { (2018) }\end{array}$ & $29(26-31)$ & $\begin{array}{l}\text { Hibstu } \\
(2020)\end{array}$ & $29(26-31)$ \\
\hline
\end{tabular}

\section{Publication bias assessment}

The visual assessment of the asymmetry of the funnel plot revealed the presence of publication bias, which was statistically confirmed by Egger's regression test $(\beta=16.45,95 \% \mathrm{Cl} 10.86-22.04) \mathrm{p}=0.001)$ (Figure 5).

\section{Factors associated with LARC use}

As shown in the Table 5, a summary of the data collected to determine the associated variables among LARC users among Ethiopian women during the previous five years. When compared to poor knowledge and a negative attitude, having good knowledge $(\mathrm{p}=0.001,95 \% \mathrm{Cl} 1.16-1.98)$ and a positive attitude $(\mathrm{p}=0.001,95$ percent $\mathrm{Cl}$ 1.5-2.3 were approximately two times more likely to use LARC over the past five years. When compared to those who had never used LARC before, former users were approximately four times $(P=0.001,3.56,95 \% \mathrm{Cl} 2.55$ - 
4.57) more likely to utilize it again. Age of women 25-34 less likely to use LARC than those aged below 25 or above 35 years $(P=0.001,95 \% \mathrm{Cl}$ 0.24-0.65). Occupation, discussion with husband, health provider counselling, parity, and educational level, while being included in many articles, had no association with LARC usage in the past five years in our review (Table5).

Table5. Analysis of factors associated with use of LARC among Ethiopian women for the last five years, 2021

\begin{tabular}{|c|c|c|c|c|c|c|c|c|c|}
\hline \multirow[t]{2}{*}{ Factors } & \multirow[t]{2}{*}{ Comparison group } & \multirow{2}{*}{$\begin{array}{l}\text { Number } \\
\text { of } \\
\text { studies }\end{array}$} & \multirow[t]{2}{*}{ OR (95\%) } & \multirow{2}{*}{$\begin{array}{l}\mathrm{P} \\
\text { values }\end{array}$} & \multicolumn{4}{|c|}{ heterogeneity } & \multirow{2}{*}{$\begin{array}{l}\text { Publication } \\
\text { bias } \\
\text { (Egg's } \\
\text { test) } \\
\text { P values }\end{array}$} \\
\hline & & & & & $\begin{array}{l}\mathrm{Q} \\
\text { value }\end{array}$ & $\mathrm{df}$ & $\mathrm{I}^{2}$ & $\begin{array}{l}\mathrm{P} \\
\text { values }\end{array}$ & \\
\hline Parity & $\geq 5$ vs $<5$ & 5 & $\begin{array}{l}1.09 \\
(0.4-1.8)\end{array}$ & 0.669 & 2.36 & 4 & 0 & 0.002 & 0.137 \\
\hline Knowled-ge & $\begin{array}{l}\text { Good knowledge vs } \\
\text { poor knowledge }\end{array}$ & 11 & $\begin{array}{l}1.6 \\
(1.16- \\
1.98)\end{array}$ & 0.001 & 16.54 & 10 & 39.6 & 0.085 & 0.001 \\
\hline Attitude & Positive vs negative & 10 & $\begin{array}{l}1.9(1.5- \\
2.3)\end{array}$ & 0.001 & 12.36 & 9 & 35.3 & 0.136 & 0.001 \\
\hline $\begin{array}{l}\text { Previous use of } \\
\text { LARC }\end{array}$ & Yes vs No & 5 & $\begin{array}{l}3.56(2.55- \\
4.57)\end{array}$ & 0.001 & 5.25 & 4 & 23.7 & 0.263 & 0.161 \\
\hline $\begin{array}{l}\text { Health provider } \\
\text { counselling }\end{array}$ & Yes vs No & 8 & $\begin{array}{l}1.18(0.85- \\
1.5)\end{array}$ & & 21.52 & 7 & 67.5 & 0.003 & 0.002 \\
\hline $\begin{array}{l}\text { Educational } \\
\text { level }\end{array}$ & $\begin{array}{l}\text { Diploma and above } \\
\text { vs others* }\end{array}$ & 9 & $\begin{array}{l}1.94(0.98- \\
2.8)\end{array}$ & & 4.85 & 8 & 0 & 0.773 & 0.039 \\
\hline Age & $\begin{array}{l}25-34 \text { years vs } \\
\text { others** }\end{array}$ & 8 & $\begin{array}{l}0.44 \\
(0.26- \\
0.65)\end{array}$ & 0.005 & 20.6 & 7 & 65.1 & 0.005 & 0.005 \\
\hline $\begin{array}{l}\text { Discussion with } \\
\text { husband }\end{array}$ & Yes vs No & 8 & $\begin{array}{l}0.93 \\
(0.58- \\
1.28)\end{array}$ & & 25.41 & 7 & 72.4 & 0.001 & 0.009 \\
\hline Occupation & $\begin{array}{l}\text { Governmental } \\
\text { employee vs } \\
\text { others*** }\end{array}$ & 9 & $\begin{array}{l}1.22 \\
(0.8-1.65)\end{array}$ & 0.204 & 10.96 & 8 & 27 & 0.201 & 0.033 \\
\hline
\end{tabular}

Others* -cannot read and write, primary education, secondary education

Others $^{* *}$-age below 24 or above 35

Others $^{* * *}$ - housewives, students, merchants, private employee, daily labourer 
In Ethiopia, the prevalence of LARC and associated factors among Ethiopian women over the last five years has only been studied in modest and fragmented ways thus far. As a result, this is the first meta-analysis of its kind to describe the overall prevalence of LARC and associated factors among Ethiopian women in the previous five years. FMOH vowed to raise LARC use prevalence to $40 \%$; however our review revealed that just $29 \%$ of women utilized it, much below the country's target. The reason might be overestimation and ambition, less trained human power on the provider of LARC,availability of instruments at rural health centres and many more but far higher than the EDHS 2019 which said, prevalence of Implanon and IUCD was 9\% and 2\%, respectively(38). Reason being the study conducted in both rural and urban of Ethiopia while in our review all studies conducted at urban areas, EDHS conducted in all regions of Ethiopia while in our review, studies were conducted in some regions of Ethiopia and also the study period was different for both studies.

Study conducted at Kampala district, Uganda among women of reproductive age revealed the prevalence of LARC was $31.7 \%$ which was similar to our findings while study conducted in Nigeria tertiary hospital showed the prevalence of LARC users were $65.6 \%$ from which $75 \%$ used implanon which was far from our result and the difference might be the study conducted at tertiary hospital and the overall prevalence of usage of modern contraceptives in the country .In our review we found that having good knowledge, positive attitude and previous use of LARC has been associated with use of LARC over the past five years. Study conducted in Nigeria (39) showed previous use of LARC, positive attitude and good knowledge significantly associated with use of LARC. Different studies conducted in Kenya(40),Nepal(41), Pakistan(42) showed previous use of LARCs, good knowledge and positive attitude associated with use of LARC among women of reproductive age

\section{Strength and Limitations}

The investigators used extensive and comprehensive search strategies from multiple databases. Published, unpublished studies and grey literature were included .detailed search was done in order to avoid duplication of similar study elsewhere. We got high heterogeneity and we assessed the possible of the cause by leave one sensitivity analysis and subgroup analysis. In our review we tried to determine the associated factors for LARC users. Although the literature search was systematic and assessed all related studies within the desired scope, it is possible that relevant publications, e.g. publications reported in non-English language and local languages must have been missed. This may affect the finding's inclusiveness. This study doesn't include any findings (studies) from Benishangul-gumuz, Somalia and Tigray Region. This may affect the generalization of this study but still, the study will be applicable to all parts of Ethiopia.

\section{Declarations}

\section{Acknowledgments}

Not applicable.

\section{Declaration of conflict of interests}

The authors declared that they have no conflicts of interest for this work

\section{Ethics Approval}


Not applicable

\section{Funding}

We did not receive any funding for this work

\section{Informed consent}

Not applicable

\section{Data availability}

all relevant data are available within the paper.

\section{References}

1. Gebru AA, Areas AF, Gebrekidan KG, Tekle W, Hailu Y. Assessment of factors affecting long acting of family planning utilization in Adigrat town, Tigray, north-East Ethiopia. American J Health Res. 2015;3(4):239-47.

2. Dejenu G, Ayichiluhm M, Abajobir AA. Prevalence and associated factors of unmet need for family planning among married women in Enemay District, Northwest Ethiopia: a comparative cross-sectional study. Global J Med Res. 2013;13(4).

3. Cleland J, Conde-Agudelo AP. H., Ross, J., \& Tsui, A. Contraception and health, Lancet.380(9837):149-56.

4. Kesetebirhan A. National guideline for family planning services in Ethiopia. Federal Democratic Republic of Ethiopia, Ministry of Health. 2011.

5. CSA-Ethiopia I. International: Ethiopia Demographic and Health Survey 2011. Central Statistical Agency of Ethiopia and ICF International Addis Ababa, Ethiopia and Calverton, Maryland, USA. 2012.

6. Lesley H. VN, Jane D. Understanding Long-Acting Reversible Contraception: An In-Depth Investigation into Sub-Dermal Contraceptive Implant Removal amongst Young Women in London. April 2013.

7. Regesu AH, Genemo GA. Predictors of Long Acting and Permanents Contraceptive Methods Utilization among Married Women of Reproductive Age in Adama Town, Oromia Region, South East Ethiopia, 2014.

8. Bulto GA, Zewdie TA, Beyen TK. Demand for long acting and permanent contraceptive methods and associated factors among married women of reproductive age group in Debre Markos Town, North West Ethiopia. BMC women's health. 2014;14(1):1-12.

9. Ababa A. Federal democratic republic of Ethiopia ministry of health. Ethiopia: Postnatal Care. 2003.

10. Page MJ, McKenzie JE, Bossuyt PM, Boutron I, Hoffmann TC, Mulrow CD, et al. The PRISMA 2020 statement: an updated guideline for reporting systematic reviews. Bmj. 2021;372.

11. Abdu Muhammed M, Abdo R. Long-acting Reversible Contraceptive Utilization and Its Associated Factors among Family Planning Users in Pastoral Communities of Afar Region, Ethiopia: A Facility-based Crosssectional Study. Journal of Midwifery and Reproductive Health. 2020;8(1):2022-32.

12. Arero WD, Teka WG, Hebo HJ. Prevalence and pattern of long acting reversible contraception (LARC) methods use in immediate postpartum period at Jimma University Medical Center, Ethiopia. 2019.

13. Asegidew W, Tariku B, Kaba M, Getachew S, Ketsela K. Acceptance and positive attitude increased utilization of long acting and permanent family planning methods among reproductive age group women 
from Debre Berhan District, Ethiopia: quantitative and qualitative analysis. J Community Med Health Educ. 2017;7(541):2161-0711.1000541.

14. Ayenew AA. Determinants of long acting reversible contraceptive Utilization in Bahir Dar city, Ethiopiaresults from institutional based cross sectional study. 2019.

15. Bewket Zeleke L, Gella MM, Almaw Derseh H, Alemu AA, Abebe Kassahun E, Gelaw KA. Utilization of longacting contraceptive methods and associated factors among female health care providers in East Gojjam Zone, Northwest Ethiopia, in 2018. BioMed research international. 2019;2019.

16. Beyene D, Assefa N, Dassie Y, Lolaso T. LEVEL AND FACTORS ASSOCIATED WITH THE USE OF LONG ACTING REVERSIBLE CONTRACEPTIVE METHODS AMONG MARRIED WOMEN IN SHONE TOWN ADMINISTRATION, HADIYA ZONE, SOUTHERN ETHIOPIA. Ethiopian Journal of Reproductive Health. 2019;11(2):9-.

17. Biza N, Abdu M. Long acting reversible contraceptive use and associated factors among contraceptive users in amhara region, ethiopia, 2016. A community based cross sectional study. Medico Research Chronicles. 2017;4(05):469-80.

18. Dake SK, Abiso TL. Reversible Long Term Contraceptives Utilization among Married Women of Reproductive Age Group in Areka Town, Southern Ethiopia. Ethiopian Journal of Health Sciences. 2020;30(6).

19. Fekadu H, Kumera A, Yesuf E, Hussien G, Tafa M. Prevalence and determinant factors of long acting contraceptive utilization among married women of reproductive age in Adaba Town, West Arsi Zone, Oromia, Ethiopia. Journal of Women's Health Care. 2017;6(1):2167-0420.1000360.

20. Gelagay AA, Koye DN, Yeshita HY. Factors affecting long acting and permanent contraceptive methods utilization among HIV positive married women attending care at ART clinics in Northwest Ethiopia. Archives of Public Health. 2018;76(1):1-9.

21. Getahun DS, Wolde HF, Muchie KF, Yeshita HY. Utilization and determinants of long term and permanent contraceptive methods among married reproductive age women at Janamora district, northwest Ethiopia. BMC research notes. 2018;11(1):1-6.

22. Gujo AB, Kare AP. Utilization of Long-Acting Reversible Contraceptives and Associated Factors Among Reproductive Age Women Attending Governmental Health Institutions for Family Planning Services in Wondo Genet District, Sidama, National Regional State, Southern Ethiopia. Health Services Research and Managerial Epidemiology. 2021;8:23333928211002401.

23. Hibstu DT, Alemayehu A. Long acting reversible contraceptives utilization and associated factors among women of reproductive age in Arsi Negele town, Southeastern Ethiopia. Contraception and Reproductive Medicine. 2020;5:1-7.

24. Hurissa AB. Utilization of Long Acting and Permanent Contraceptive Methods and Associated Factors among Married Women of Reproductive Age in Bishoftu Town, Oromia Regional State, Ethiopia: Addis Ababa University; 2017.

25. Kebede B, Belete M, Negeri H, Halil H, Anshebo A, Abdo R. Magnitude and Factors Affecting Long-acting Reversible Contraceptive Utilization among Reproductive Age Women in Silti District, Southern Ethiopia. J Women's Health Care. 2020;9(494):2167-0420.20.

26. Mariam T, Kebede Y, Shibru A, Birhanu A. Utilization of reversible long acting contraceptive methods and associated factors among women getting family planning service in governmental health institutions of 
Gondar City, Northwest Ethiopia 2015. Austin J Public Health Epidemiol. 2018;5(1):1069.

27. Meleko A, Sileshi S, Bekele Y, Daniel A, Getawey A. Utilization of long acting reversible contraceptive methods and its associated factors among women of reproductive age groups in Mizan-Aman Town, Bench Maji Zone. J Women's Health Issues Care. 2017;6(6):2.

28. Mesfin Y, Wallelign A. Long-acting reversible contraception utilization and associated factors among women in extended postpartum period in southern Ethiopia. Archives of Public Health. 2021;79(1):1-7.

29. Mohammed E, Tadese L, Agero G. Acceptance of long acting reversible contraceptive methods and associated factors among reproductive age women in Adama Town, Oromia Regional State, Ethiopia. Clin Med Res. 2017;6(2):53.

30. Shiferaw K, Musa A. Assessment of utilization of long acting reversible contraceptive and associated factors among women of reproductive age in Harar City, Ethiopia. Pan African medical journal. 2017;28(1).

31. Tebeje B, Workneh D. Prevalence, perceptions and factors contributing to long acting reversible contraception use among family planning clients, Jimma Town, Oromiya Region, South-West Ethiopia. J Women's Health Care. 2017;6(1):1-10.

32. Teshome G, Woldeyohanis F, Deyessa N. Long acting and permanent contraceptive use in Arada Sub City, Addis Ababa, Ethiopia, 2017. J Community Med Health Educ. 2018;8(618):2161-0711.1000618.

33. Tilahun A, Yoseph A, Dangisso MH. Utilization and predictors of long acting reversible contraceptive methods among reproductive age women in Hawassa city, South Ethiopia: a community based mixed methods. Contraception and reproductive medicine. 2020;5(1):1-11.

34. Woldu BF, Ermolo TL, Lemu LG, Gejo NG. Long-acting reversible contraception utilization and associated factors among women in extended postpartum period in Hossana town, southern Ethiopia: cross sectional study. Contraception and Reproductive Medicine. 2020;5(1):1-6.

35. Wondyfraw AA, Kassaw NA. Magnitude of Long-acting and Permanent Family Planning Practice and Its Factors Among Contraceptive Users: A Cross-sectional Study. 2021.

36. Yemaneh Y, Birie B. Assessment of knowledge, attitude and utilization of long acting family planning method among women of reproductive age Groupe in Mizan-Aman Twon, bench-Majizone, south West Ethiopia, 2016. Integr J Glob Health. 2017;1(2).

37. Zenebe CB, Adefris M, Yenit MK, Gelaw YA. Factors associated with utilization of long-acting and permanent contraceptive methods among women who have decided not to have more children in Gondar city. BMC women's health. 2017;17(1):1-7.

38. FMOH. mini demographic and health survey 2019.

39. Aduloju OP, Akintayo AA, Adefisan AS, Aduloju T. Utilization of Long-Acting Reversible Contraceptive (LARC) Methods in a tertiary hospital in southwestern Nigeria: A Mixed Methods Study. The Journal of Obstetrics and Gynecology of India. 2021;71(2):173-80.

40. Nasri M. Prevalence and factors associated with uptake of long-acting reversible contraceptives in Kiambu Level Five Hospital Kiambu County: University of Nairobi; 2020.

41. Bhandari R, Pokhrel KN, Gabrielle N, Amatya A. Long acting reversible contraception use and associated factors among married women of reproductive age in Nepal. PloS one. 2019;14(3):e0214590.

42. Khan MS, Hashmani FN, Ahmed O, Khan M, Ahmed S, Syed S, et al. Quantitatively evaluating the effect of social barriers: a case-control study of family members' opposition and women's intention to use 


\section{Figures}

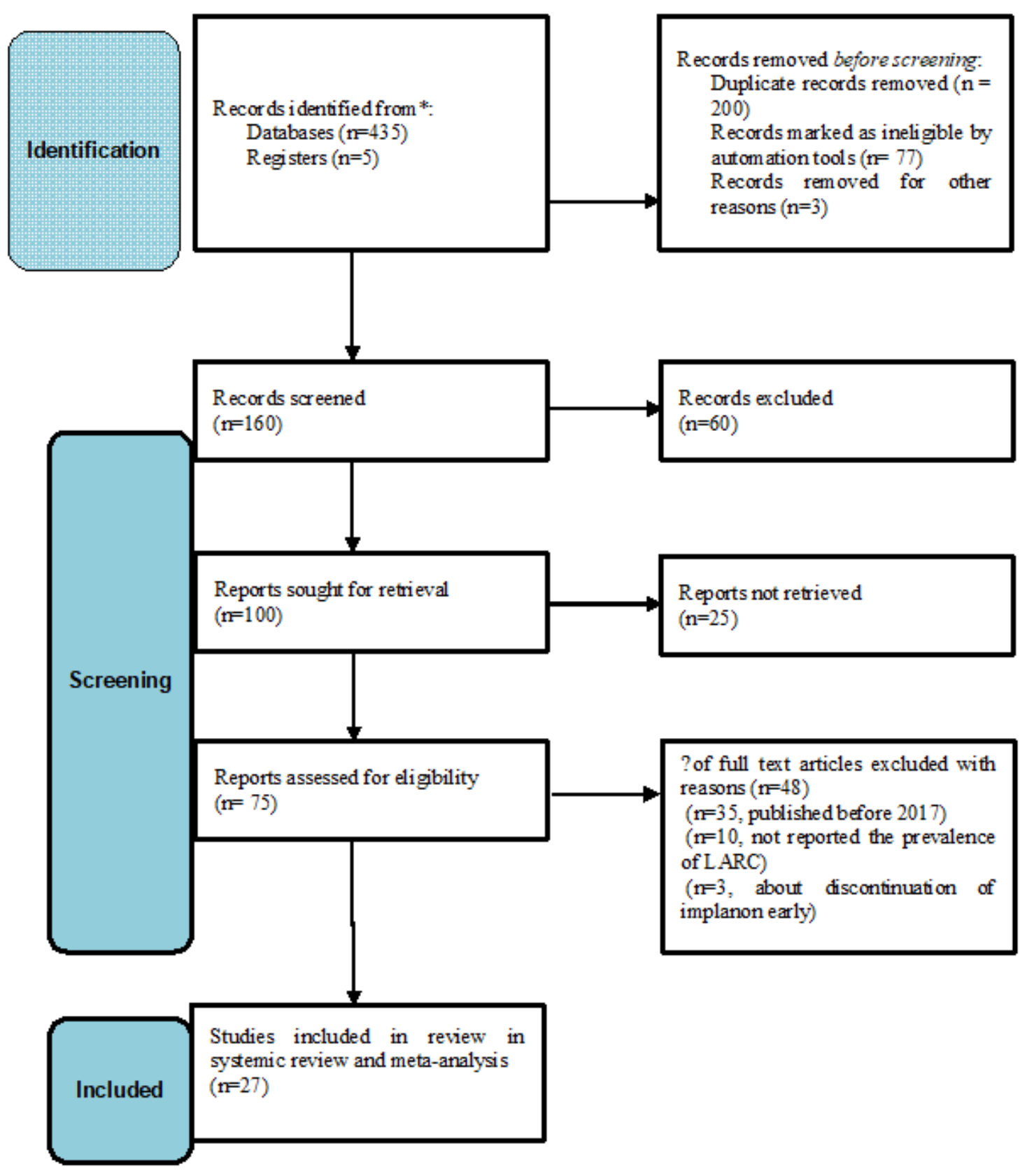

Fig1. PRISMA flow diagram for study selection

\section{Figure 1}

See image above for figure legend. 


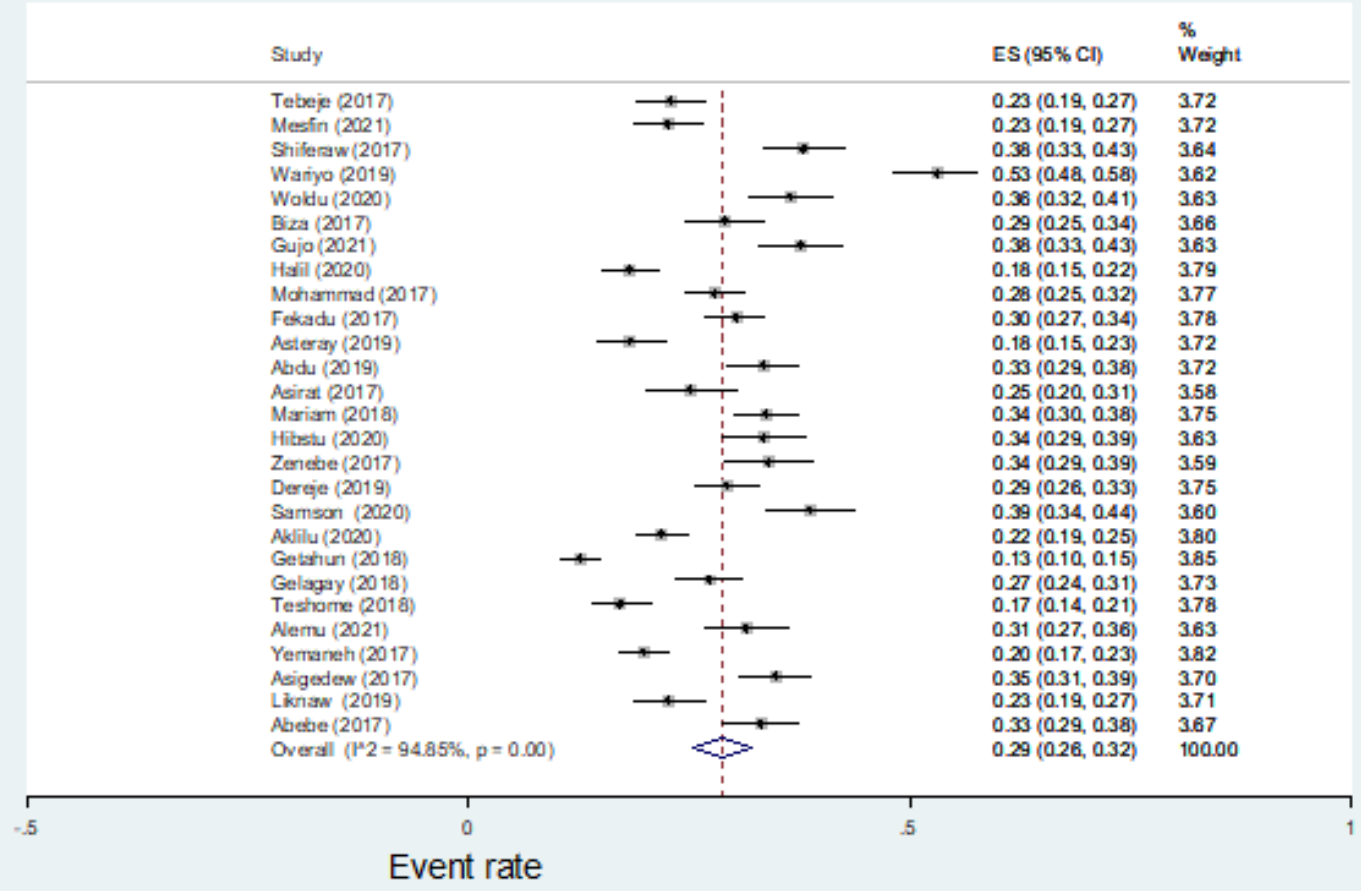

Figure 2: Forest plot showing pooled prevalence of LARC among women in Ethiopia for the last five years, 2021

Figure 2

See image above for figure legend. 


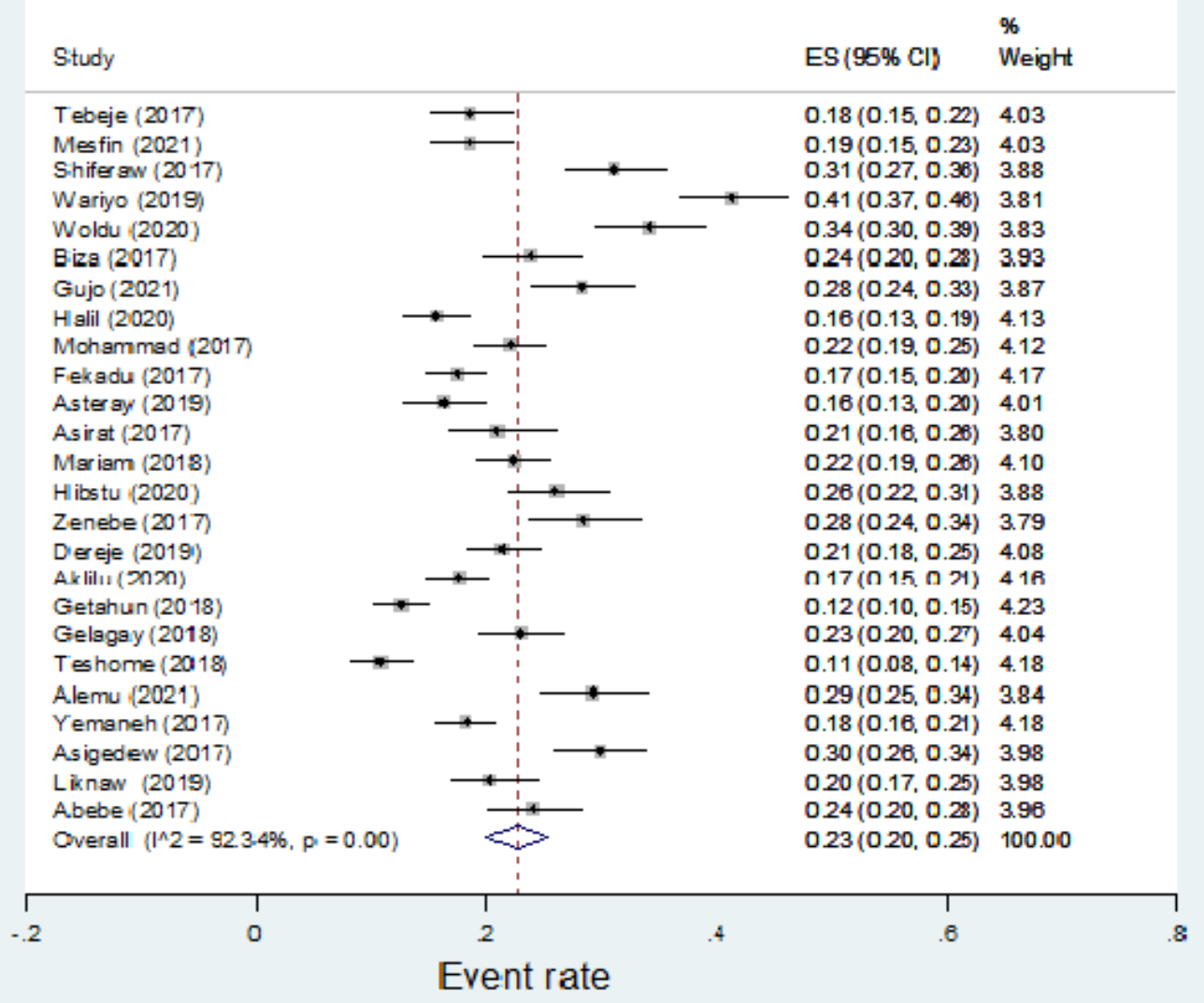

Figure 3: Forest plot showing pooled prevalence of Implanon among women in Ethiopia the last five years, 2021

\section{Figure 3}

See image above for figure legend. 


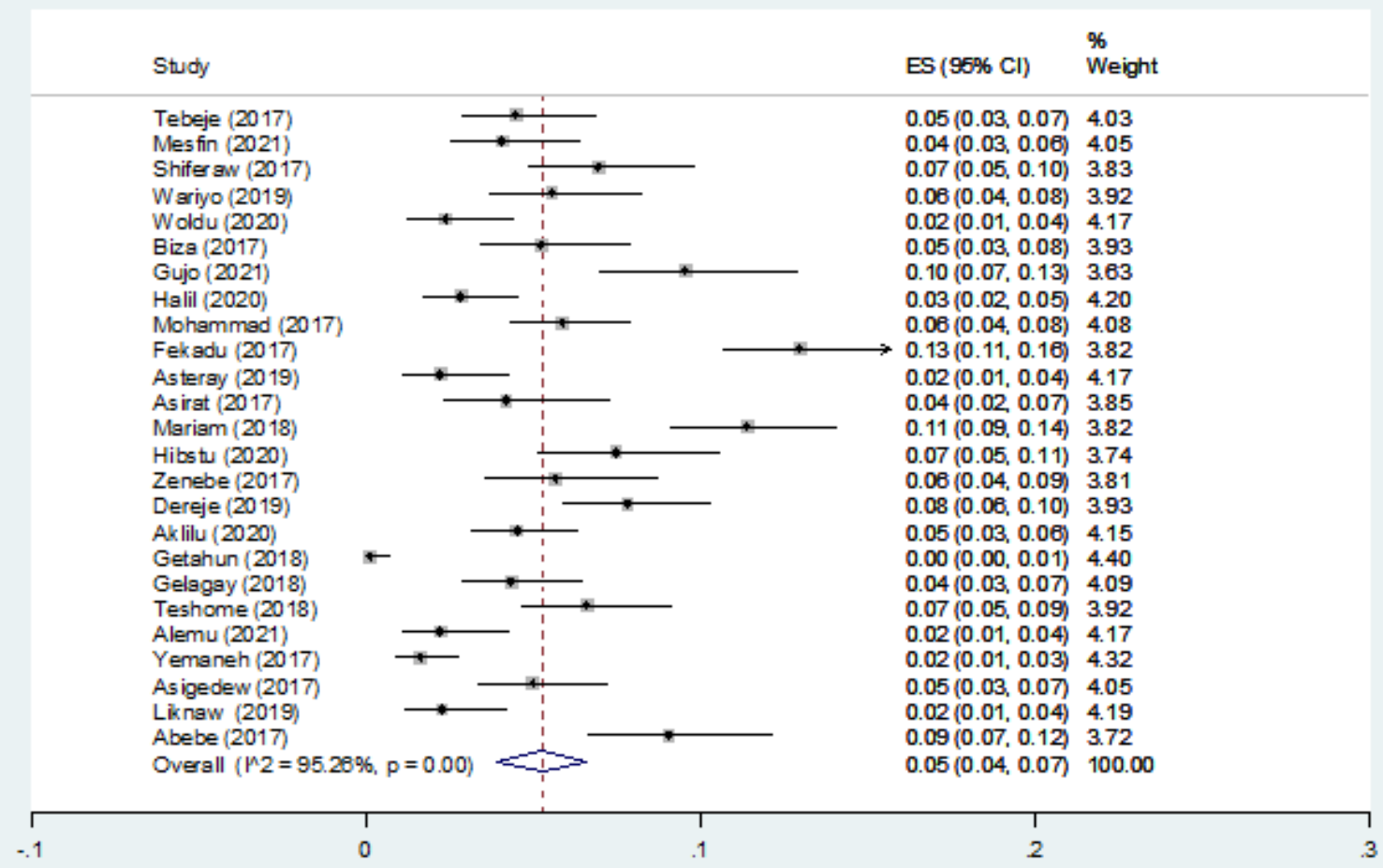

Event rate

Figure 4: Forest plot showing pooled prevalence of IUCD among women in Ethiopia for the last five years, 2021

\section{Figure 4}

See image above for figure legend. 


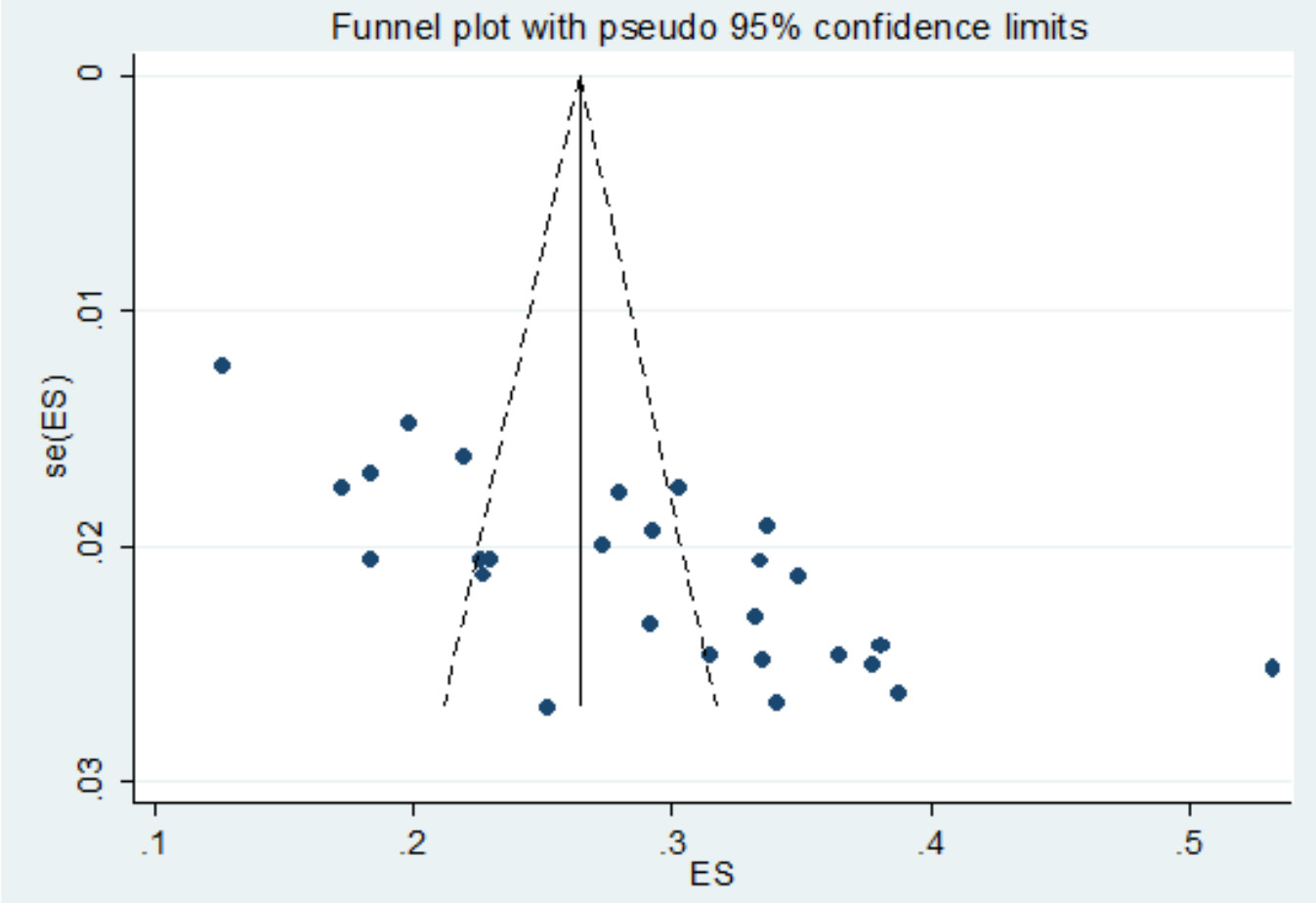

Figure 5: Assessment of Publication bias

\section{Figure 5}

See image above for figure legend. 